\title{
Quantitative EEG during normal aging: association with the Alzheimer's disease genetic risk variant in PICALM gene
}

\author{
Natalya V. Ponomareva a,b,*, Tatiana V. Andreeva ${ }^{\text {b,c }}$, Maria S. Protasova ${ }^{\text {b }}$, Lef I. Shagam ${ }^{\text {, }}$, \\ Daria D. Malina ${ }^{\mathrm{a}}$, Andrey Yu. Goltsov ${ }^{\mathrm{b}}$, Vitaly F. Fokin ${ }^{\mathrm{a}}$, Sergey N. Illarioshkin ${ }^{\mathrm{a}}$, \\ Evgeny I. Rogaev b,c, d,e,** \\ ${ }^{a}$ Research Center of Neurology, Moscow, Russia \\ ${ }^{\mathrm{b}}$ Vavilov Institute of General Genetics, RAS, Moscow, Russia \\ ${ }^{c}$ Center of Brain Neurobiology and Neurogenetics, Institute of Cytogenetics and Genetics RAMS, Novosibirsk, Russia \\ ${ }^{\mathrm{d}}$ Center of Genetics and Genetic Technologies, Lomonosov Moscow State University, Moscow, Russia \\ ${ }^{\mathrm{e}}$ Department of Psychiatry, Brudnick Neuropsychiatric Research Institute, University of Massachusetts Medical School, Worcester, MA, USA
}

\section{A R T I C L E I N F O}

\section{Article history:}

Received 17 March 2016

Received in revised form 14 November 2016

Accepted 11 December 2016

Available online 20 December 2016

\section{Keywords:}

Electroencephalography (EEG)

PICALM

Aging

Alzheimer's disease (AD)

\begin{abstract}
A B S T R A C T
Genome-wide association studies have identified novel risk variants for Alzheimer's disease (AD). Among these, a gene carrying one of the highest risks for AD is PICALM. The PICALM rs3851179 A allele is thought to have a protective effect, whereas the $G$ allele appears to confer risk for AD. The influence of the PICALM genotype on brain function in nondemented subjects remains largely unknown. We examined the possible effect of the PICALM rs3851179 genotype on quantitative electroencephalography recording at rest in 137 nondemented volunteers (age range: 20-79 years) subdivided into cohorts of those younger than and those older than 50 years of age. The homozygous presence of the AD risk variant PICALM GG was associated with an increase in beta relative power, with the effect being more pronounced in the older cohort. Beta power elevation in resting-state electroencephalography has previously been linked to cortical disinhibition and hyperexcitability. The increase in beta relative power in the carriers of the $\mathrm{AD}$ risk PICALM GG genotype suggests changes in the cortical excitatory-inhibitory balance, which are heightened during normal aging.
\end{abstract}

(C) 2016 Elsevier Inc. All rights reserved.

\section{Introduction}

Genetic predisposition and increasing age are the greatest known risk factors for AD. Mutations of the APP, presenilin-1 (PSEN1), and presenilin-2 (PSEN2) genes are causative factors for early onset AD (Goate et al., 1991; Levy-Lahad et al., 1995; Rogaev et al., 1995; Sherrington et al., 1995). Polymorphisms of the apolipoprotein $E(A p o E)$ gene are the most prevalent genetic risk factors for late onset $\mathrm{AD}$ in Caucasian ethnic groups, including the Russian population (Farrer et al., 1997; Rogaev, 1999; Saunders et al., 1993; Schmechel et al., 1993). Recent genome-wide association studies have identified novel risk variants for AD (Benitez et al., 2014; Chauhan et al., 2015; Harold et al., 2009; Lambert et al., 2009; Liu et al., 2013; Naj et al., 2014). The putative epistatic interaction

\footnotetext{
* Corresponding author at: Brain Research Department, Research Center of Neurology, RAMS, Obucha-by-street, 5, Moscow 105064, Russia. Tel.: +7(495)9170765; fax: +7(495)916-0595

** Corresponding author at: BNRI, Worcester, BNRI, MA 01604, USA. Tel.: +1 (774) 455 4325; fax: +1 (508) 8568438

E-mail addresses: ponomare@yandex.ru (N.V. Ponomareva), Evgeny.Rogaev@ umassmed.edu, Rogaev@vigg.ru (E.I. Rogaev).
}

of the novel risk variants with the $A P O E \varepsilon 4$ variant in the risk for $A D$ has been demonstrated (Golenkina et al., 2010; Naj et al., 2014). Among the identified genes, phosphatidylinositol clathrin assembly lymphoid-myeloid leukemia (PICALM, chrm 11q14) is currently one of the top 6 risk genes for $\mathrm{AD}$ in the AlzGene database (http://www. AlzGene.org).

Understanding how the genes identified in association studies influence $\mathrm{AD}$ pathogenesis can potentially contribute to the earlier prediction of $A D$ and the use of personalized prevention strategies in individuals at risk for AD.

The PICALM protein has been implicated in clathrin-mediated endocytosis (Ford et al., 2001). Clathrin-mediated endocytosis is responsible for the internalization of receptors, the recycling of membrane components, and the regulation of autophagic processes (Xu et al., 2015). Convincing data indicate that genetically directed changes in PICALM function lead to alterations in APP processing through endocytic pathways, amyloid beta $(A \beta)$ production (Xiao et al., 2012) and $A \beta$ clearance into the bloodstream (Ando et al., 2013; Baig et al., 2010; Parikh et al., 2014). PICALM may also contribute to $\mathrm{AD}$ development due to defects in autophagy and the clearance of tau, which is an autophagy substrate (Moreau et al., 
2014). The PICALM protein is associated with neurofibrillary tangles and is abnormally cleaved in Alzheimer's brains (Ando et al., 2013). PICALM may cause synaptic perturbations by modulating the abundance of the glutamate receptor subunit GluR2 (Harel et al., 2011; Harold et al., 2009) and may influence AD risk by disrupting iron homeostasis and lipid metabolism (Xu et al., 2015).

The influence of the PICALM genotype on hippocampal volume and the thickness of the entorhinal cortex was found in patients with $\mathrm{AD}$ and mild cognitive impairment $(\mathrm{MCI})$, and in normal controls (Biffi et al., 2010). Gene-wide scoring highlighted PICALM as the most significant gene associated with entorhinal cortical thickness (Furney et al., 2011).

However, the mechanism by which PICALM polymorphisms influence brain function in nondemented subjects remain largely unknown. The SNP rs3851179, which was the first PICALM SNP associated with AD risk (Harold et al., 2009), is located in a noncoding region $\sim 80 \mathrm{~kb} 5^{\prime}$ of PICALM. There are several PICALM SNPs (e.g., rs543293, rs659023, rs7110631, rs7941541, and rs3851179) in linkage disequilibrium with each other and associated with $\mathrm{AD}$ (Harold et al., 2009; Raj et al., 2012; Xu et al., 2016). Hence, the variant rs3851179 investigated in the present study is tagging the AD-associated haplotype.

Electroencephalography (EEG) is a powerful and cost-effective method for studying alterations in brain function during normal and pathological aging. EEG reflects the integrated synaptic activity of large populations of neurons, which progressively deteriorates in normal and physiological aging (Buzsaki, 2006). Recent data showed that EEG may be a valuable biomarker of the development of the pathologic processes in AD (Babiloni et al., 2006a; Jeong et al., 2004; Prichep et al., 2006; Moretti et al., 2012). Such biomarkers can be helpful to estimate the effect of potential therapies to prevent or delay the onset of neurodegenerative diseases (Illarioshkin et al., 2004; Masdeu et al., 2012).

The primary EEG abnormalities in AD patients consist of a shift of the power spectrum to lower frequencies and a decrease in the coherence of fast rhythms (Jelic et al., 1997; Jeong, 2004). AD patients exhibit a slowing of the dominant EEG frequency, increased delta and theta power, and decreased alpha power compared to healthy age-matched controls (Babiloni et al., 2014; Rossini et al., 2007, van Straaten et al., 2014). MCI, which is in most cases a prodromal stage of $\mathrm{AD}$, has $\mathrm{EEG}$ characteristics intermediate of those of normal subjects and AD patients (Babiloni et al., 2006a). Longitudinal studies have revealed EEG-based predictors of future decline in $\mathrm{MCI}$ patients and even in healthy elderly subjects (Babiloni et al., 2014; Prichep et al., 2006; Van der Hiele et al., 2008).

Healthy aging is associated with an amplitude decrease in the posterior alpha rhythm, with the anteriorization of the alpha activity and the slowing of alpha frequency (Babiloni et al., 2006b; Klimesch, 1999; Ponomareva et al., 2013; Tsuno et al., 2002; Volf and Gluhih, 2011). Several, but not all, studies also reported a decrease in delta activity and an increase in beta activity during physiological aging (Babiloni et al., 2006b; Vlahou et al., 2014).

EEG patterns have been suggested as promising tools to assess endophenotypes-basic heritable quantitative biological traits that more directly reflect the influence of specific genetic abnormalities than a complex disorder. Resting-state EEG characteristics are among the most heritable traits in humans, and the heritability of the spectral power of different EEG bands is in the range 70\%-90\% (van Beijsterveldt et al., 1996). EEG endophenotypes might help to clarify the role of genetic variants in brain function and disease development (De Geus, 2010).

Recent studies have demonstrated an association between EEG characteristics and $\mathrm{AD}$ risk variants in the ApoE and $C L U$ genes in $\mathrm{AD}$ and MCI patients and even in healthy adults (Babiloni et al., 2006a; Jelic et al., 1997; Lee et al., 2012; Lehtovirta et al., 2000; Ponomareva et al., 2008, 2012, 2013; Stam et al., 2003).

The effect of the PICALM genotype on EEG characteristics has not been previously investigated.

The present study aimed to determine whether the PICALM genotype influences EEG characteristics in nondemented adults, and to estimate whether this possible effect is modified over the course of aging.

\section{Materials and methods}

\subsection{Participants}

The enrolled cohort included 137 nondemented individuals (47 men and 90 women; age range: 20-79 years).

The subjects were of Russian descent from Moscow and the Moscow region. The participants underwent a neurologic examination and cognitive screening. The recruited subjects were free of dementia and other medical, psychiatric, and neurologic conditions. The exclusion criteria included a history of neurologic and psychiatric diseases, any type of memory impairment, signs of clinical depression or anxiety, physical brain injury or other medical conditions (e.g., hypertension, diabetes, cardiac disease, or thyroid disease), or a personal history of drug or alcohol addiction.

The Spielberger State-Trait Anxiety Inventory (Spielberger et al., 1983) and the Hamilton Rating Scale for Depression (Hamilton, 1960) were used to examine anxiety and depression. The subjects were evaluated with the mini-mental state examination and Clinical Dementia Rating scale (Hughes et al., 1982). Only subjects with mini-mental state examination scores of 28 or more and Clinical Dementia Rating scores of 0 were included in the study. All subjects were right-handed.

Written informed consent was obtained from all the participants. The experimental protocol for this study was approved by the local ethics committee. ApoE genotyping was performed for all participants, and the effect of the ApoE genotype on the EEG characteristics was statistically controlled.

All subjects were divided into subgroups according to the PICALM (PICALM AA and AG and PICALM GG) polymorphisms. The PICALM $A A$ and $A G$ group included subjects with the homozygous PICALM AA or heterozygous PICALM AG genotypes. The PICALM GG group consisted of subjects with the homozygous PICALM GG genotype. Each group was further subdivided into cohorts of those younger than and those older than 50 years of age (Table 1 ).

Table 1

Demographic characteristics of participants

\begin{tabular}{|c|c|c|c|c|c|c|}
\hline \multirow[t]{2}{*}{ Variable } & \multicolumn{2}{|c|}{ Younger cohort age range $(20-50)$} & \multicolumn{2}{|c|}{ Older cohort age range $(51-79)$} & \multicolumn{2}{|c|}{ All participants age range $(20-79)$} \\
\hline & $\overline{P I C A L M ~ A A \text { and } A G}$ & $\overline{P I C A L M ~ G G}$ & $\overline{P I C A L M ~ A A \text { and } A G}$ & $\overline{P I C A L M ~ G G}$ & $\overline{P I C A L M ~} A A$ and $A G$ & PICALM GG \\
\hline $\mathrm{N}$ & 50 & 23 & 39 & 25 & 89 & 48 \\
\hline Age (y) & $34.4 \pm 1.4$ & $37.3 \pm 2.3$ & $63.6 \pm 1.3$ & $60.6 \pm 1.3$ & $47.2 \pm 1.8$ & $49.4 \pm 2.1$ \\
\hline Sex (men/women; men\%) & $18 / 32 ; 36 \%$ & $8 / 15 ; 34.8 \%$ & $14 / 25 ; 35.9 \%$ & $7 / 18 ; 28 \%$ & $32 / 57 ; 36 \%$ & $15 / 33 ; 31.3 \%$ \\
\hline
\end{tabular}

The data are presented as the means and standard errors. 


\subsection{EEG procedure}

The registration and evaluation of EEG was carried out in accordance with International Pharmaco-EEG Society guidelines (Jobert et al., 2013; Versavel et al., 1995). All recordings were obtained in the afternoon from 3 to 4 PM. EEGs were recorded for 3 minutes during the resting state, with the subjects sitting comfortably in a chair. They were asked to close their eyes and relax, but to stay awake during the recording. To maintain a constant level of vigilance, an experimenter monitored the subject, and the EEG traces on-line and verbally alerted the subject any time when there were signs of behavioral and/or EEG drowsiness.

The EEGs were recorded on Nihon Kohden 4217G EEG (Japan) using a time constant of 0.3 seconds. The high frequency cutoff was $45 \mathrm{~Hz}$. The $14 \mathrm{Ag} / \mathrm{AgCl}$ electrodes were placed according to the international 10-20 system at the 02, 01, P4, P3, C4, C3, F4, F3, Fp2, Fp1, T4, T3, F8, and F7 positions. Linked ears served as the reference. The electrode impedance did not exceed $10 \mathrm{k} \Omega$. During the recordings, 180 seconds of EEG at rest was simultaneously sampled at $256 \mathrm{~Hz}$ per channel and stored on a computer for further analysis offline. The EEG was reviewed visually for artifacts, which were eliminated from the subsequent analysis. After the artifacts were eliminated, segments of the resting EEG of 120 seconds in duration were selected for further analysis.

\subsection{EEG analysis}

Frequencies below $2 \mathrm{~Hz}$ and above $35 \mathrm{~Hz}$ were eliminated using digital filtering. Thirty 4-s artifact-free resting EEG epochs were processed using fast Fourier transform. The relative powers (\% of the total EEG power) of the delta $(2.00-3.99 \mathrm{~Hz})$, theta (4.00-7.99), alpha (8.00-12.99), beta 1 (13.00-19.99), and beta 2 (20.00-30.00) bands and the occipital (O2, O1), parietal (P4, P3), central (C4, C3), frontal 1 (F4, F3), frontal 2 (Fp2, Fp1), mid-temporal 2 (T4, T3), and anterior temporal (F8, F7) regions were calculated. Log transformations of the relative power of the various bandwidths in each derivation were calculated to compensate for data skewedness, according to the recommendations of John et al. (1980), using the formula $\log (x /[1-x])$, where $x$ is the fraction of total power for each 4-s sample. The average log relative power for each frequency band was then calculated. The details of the spectral analysis procedures have been previously described (Ponomareva et al., 2008, 2012, 2014).

\subsection{Genetic analysis}

Genomic DNA was isolated from peripheral venous blood using the standard phenol-chloroform extraction method or a Qiagen DNA isolation kit. Genotyping was performed using polymerase chain reaction (PCR), followed by restriction fragment length polymorphism analysis. Amplification was performed according to the manufacturer's instructions using both the Tercyc DNA amplifier (DNA technology, Russia) and the GeneAmp PCR System 9700 Thermal Cycler (Applied Biosystems).

The restriction fragment length polymorphism analysis was developed to genotype the rs3851179 polymorphism of PICALM. We designed oligonucleotide primers flanking the polymorphic region of the PICALM gene that contains the rs3851179 polymorphism primers: PICALM F sequence $5^{\prime} \rightarrow 3^{\prime}$ CTCCTTCAACAGCTGCTCCT and PICALM- $R$ sequence $5^{\prime} \rightarrow 3^{\prime}$ TGCTACCCATGTCATCCTCA.

PCR was performed using the Isogen "Core" kits according to the manufacturer's instructions. Each assay contained $0.2 \mu \mathrm{M}$ of each primer and 30-100 ng of genomic DNA and was run on a GeneAmp PCR System 9700 Thermal Cycler (Applied Biosystems). The PCR reaction conditions were as follows: primary denaturation at $95{ }^{\circ} \mathrm{C}$ for 1 minute, 35 cycles of denaturation at $95{ }^{\circ} \mathrm{C}$ for 30 seconds, annealing at $57{ }^{\circ} \mathrm{C}$ for 45 seconds, and extension at $72{ }^{\circ} \mathrm{C}$ for 1 minute, followed by a terminal extension at $72{ }^{\circ} \mathrm{C}$ for 10 minutes. The PCR product was digested using the SspI restriction enzyme (SibEnzyme) at $37^{\circ} \mathrm{C}$ overnight. The resulting restriction fragments were analyzed using electrophoresis with $2 \%$ agarose gels (Fig. 1).

For the $G$ allele, when SspI cannot digest the PCR product, we identified one 480 bp band. Otherwise, the SspI restriction enzyme digests the PCR product and generates 2 bands, $392 \mathrm{bp}$ and $88 \mathrm{bp}$, and this is the $A$ allele.

ApoE genotyping was performed according to previously described methods (Golenkina et al., 2010).

\subsection{Statistical analysis}

Differences in the demographic and neuropsychological scores between the groups (PICALM AA and AG young, PICALM GG young, PICALM AA and AG old, and PICALM GG old) were compared using an analysis of variance (ANOVA) in the case of the normally distributed continuous variables (age and education), and the Mann-Whitney $U$ test for the categorical variables (sex).

The EEG parameters from each group were tested for normal distribution using the Shapiro-Wilk test, and in none of the cases were the data found to be skewed.

The significance of the differences between the log-transformed EEG parameters was estimated using repeated measures of ANOVA in the general linear model (GLM) with genotype (PICALM AA and $A G$ vs. PICALM GG) and age cohort (old vs. young) as the betweensubject factors, and bands as a within-subject factor. Gender and ApoE genotype were included as fixed factors. Post hoc comparisons for between-subject effects and within-subject effects were analyzed using the Duncan test, and the level of significance was set to $p<0.05$ for the post hoc comparisons.

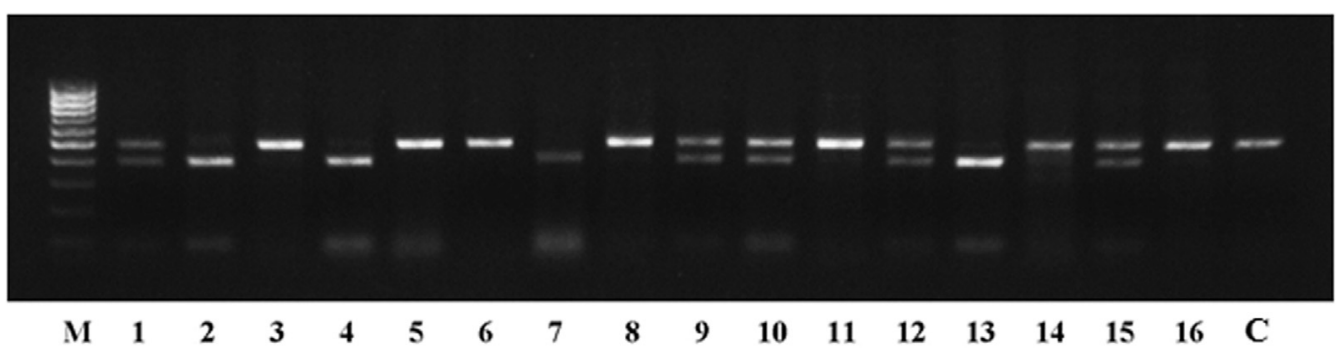

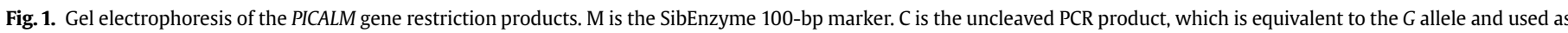

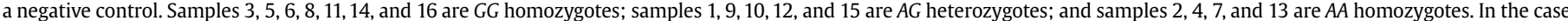

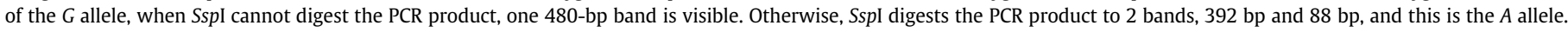
Abbreviation: PCR, polymerase chain reaction. 
We combined the groups with the PICALM AA and PICALM AG genotypes into a single group because the group with the PICALM $A A$ genotype was relatively small (22 subjects) and because the control ANOVA analysis with genotype (PICALM AA vs. PICALM AG) as the between-subject factor did not show significant differences in EEG parameters between the PICALM AA and PICALM AG groups.

\section{Results}

Table 1 shows the demographic information for the participants. There were no differences in age and sex between the PICALM GG and PICALM AA and AG subgroups in either the young or the old subgroups, or in the whole sample $(p>0.05)$. There were no significant differences in sex between the young and the old subgroups with the same PICALM genotype.

Statistical examination of the normalized EEG relative power values yielded a significant main effect for the PICALM genotype $[\mathrm{F}(1,131)=4.09, p=0.045]$. Post hoc comparisons revealed that in the entire sample, the beta 1 and beta 2 relative power in the subjects with a homozygous PICALM GG genotype was higher than that in the subjects with the PICALM $A A$ and $A G$ genotypes ( $p=0.039$ for beta 1 and $p=0.033$ for beta 2; Fig. 2).

Histograms of the distribution of the values of the beta 1 and beta 2 relative power in the carriers of the different PICALM genotypes are presented in Fig. A (Supplementary Materials). The data confirmed higher values of beta 1 and beta 2 relative power in the subjects with the PICALM GG genotype than in the individuals with the PICALM AA and $A G$ genotypes despite othe overlap among the groups.

Moreover, the distribution of these EEG parameters in the 3 genotype groups (PICALM AA, PICALM AG, and PICALM GG) indicated that the PICALM AA homozygotes had the lowest beta 1 and beta 2 relative power compared to the non-PICALM AA carriers (Fig. B. Supplementary Materials). However, the number of PICALM AA homozygotes was insufficient for an ANOVA to examine differences of the EEG parameters in the 3 genotype groups.

Fig. C (Supplementary Materials) shows examples of the EEGs in the subjects with the different PICALM genotypes. A marked increase in beta activity was revealed in the carriers of the PICALM GG genotype.

The ANOVA revealed a significant interaction between the factors age and EEG bands $[F(4,496)=3.48, p=0.008]$ in the whole sample. Post hoc comparisons demonstrated significant differences

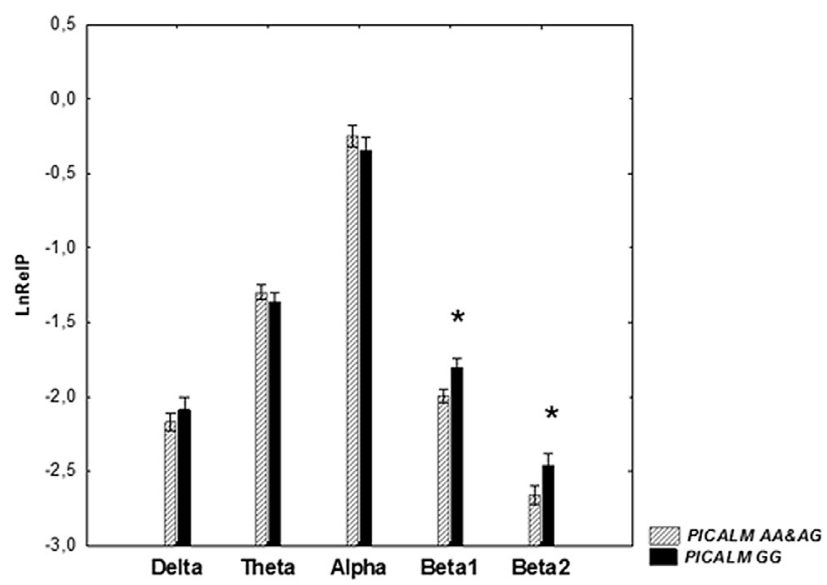

Fig. 2. Log-transformed relative power (mean and standard error) of the EEG bands in the subjects with the PICALM GG and PICALM AA and AG genotypes. ${ }^{*} p<0.05$; significant difference between the PICALM GG and PICALM AA and AG carriers. Abbreviations: EEG, electroencephalography; LnRelP, Log-transformed relative power. in the delta and beta 1 relative power between the older and the younger subjects. In the older subjects, the log-transformed delta relative power was $-2.24 \pm 0.07$, whereas in the younger individuals, this parameter was significantly higher $(-2.05 \pm 0.06$, $p=0.045$ ). The log-transformed beta power in the older cohort was $-1.80 \pm 0.05$, whereas in the younger cohort it was significantly lower $(-2.05 \pm 0.05, p=0.01)$.

Post hoc comparisons showed that in the subjects with the PICALM GG genotype, the beta 1 and beta 2 power was significantly higher in the older cohort compared to the younger cohort ( $p=$ 0.035 for beta 1 and $p=0.046$ for beta 2 ). In the older carriers of the PICALM GG genotype, beta 2 relative power was increased compared to the older carriers of the PICALM AA and AG genotypes (Fig. 3).

\section{Discussion}

This study shows that the PICALM rs3851179 polymorphism is associated with beta relative power in the resting-state EEG of nondemented adults. An increase in beta 1 and beta 2 relative power was observed in the carriers of the homozygous AD risk variant PICALM GG compared to the carriers of the protective PICALM A allele (PICALM AA and $A G$ genotypes).

This study also showed that the main effect of age was significant for the relative power in the delta and beta 1 frequency bands. Delta power was decreased, and beta power was increased in the older compared to the younger cohort. This age-related decrease in delta relative power is consistent with the results of previous studies (Babiloni et al., 2006b; Leirer et al., 2011; Vlahou et al., 2014). An increase of beta relative power during aging was previously found in many (Rossiter et al., 2014; Vlahou et al., 2014; Vysata et al., 2012), but not all, studies (Babiloni et al., 2006b).

Our results showed that the increase in relative beta power during aging was significant only in the PICALM GG genotype carriers; however, similar tendency was observed in all groups. The genetic heterogeneity of the samples may have caused the discrepancies in the results of previous studies. Accounting for genetic factors may improve the homogeneity of the results of future studies in this area.

The beta rhythm is one of the essential functional features of the brain. This rhythm has been associated with the coordination among many parts of the neocortex and the mediation of signals transmitted from higher-order structures to the lower-order structures (Siegel et al., 2012). Beta oscillations have been reported to be involved in regulating attention, motor planning and control, multisensory integration, and language processing (Donner et al., 2009; Leocani et al., 1997, Siegel et al., 2012; Spitzer and Blankenburg, 2011; Tallon-Baudry et al., 2004; von Stein et al., 1999).

The beta rhythm is generated in cortico-cortical, corticohippocampal, and cortico-basal ganglia-thalamo-cortical networks (Cannon et al., 2014, for review). Beta oscillations within these networks are dependent on the balance between excitatory glutamatergic pyramidal cells and inhibitory interneurons, with GABAergic cells playing the role of pacemakers (Bibbig et al., 2002; Yamawaki et al., 2008). A significant genetic linkage has been found for the beta frequency in resting EEG with a cluster of $G A B A_{A}$ receptor genes on chromosome 4 (Porjesz et al., 2002).

The increase in beta relative power in the resting-state EEG can be interpreted as a sign of hyperarousal, central nervous system disinhibition, and/or hyperexcitability (Enoch et al., 2008; Fernandez-Mendoza et al., 2016; Jaworska et al., 2012; Riemann et al., 2010). Elevated beta power was found to be associated with alterations of inhibitory controls, insomnia, or anxiety (Porjesz and 


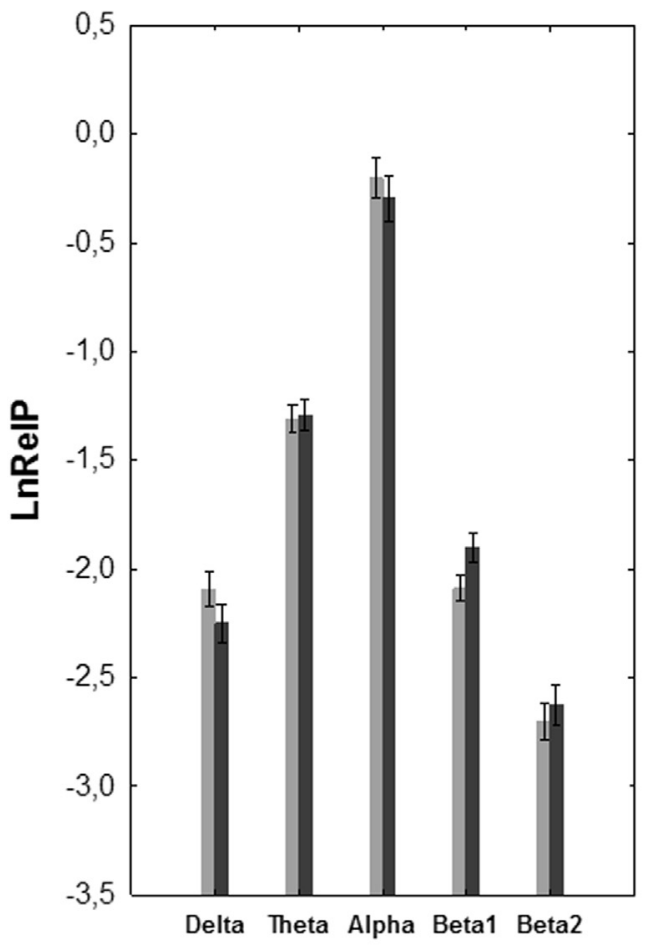

PICALM AA\&AG

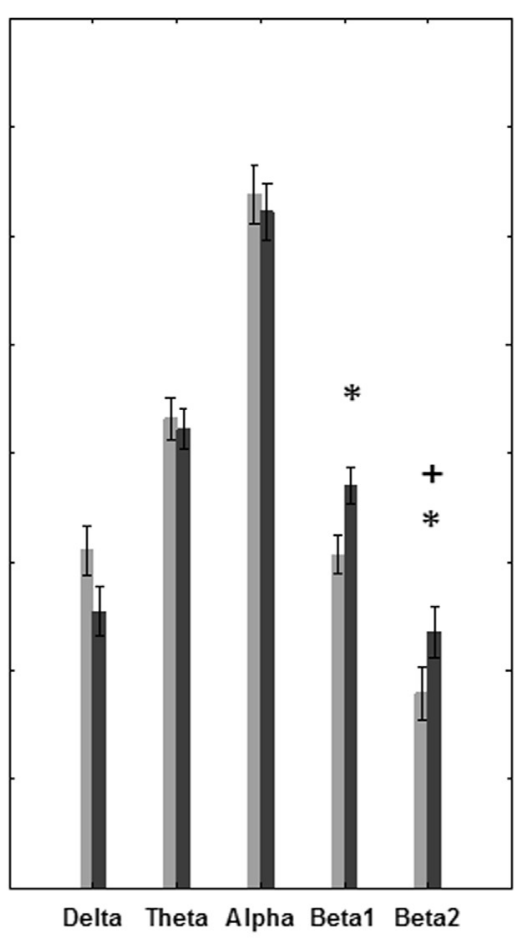

PICALM GG

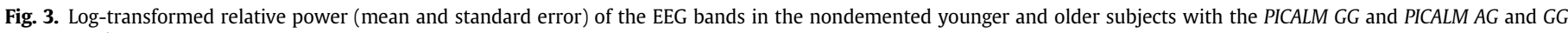

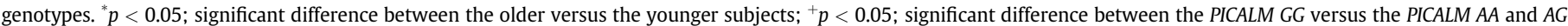
subjects. Other abbreviations as in Fig. 1.

Rangaswamy, 2007; Rangaswamy et al., 2002; Rangaswamy and Porjesz, 2014; Riemann et al., 2010; Saletu-Zyhlarz et al., 2004).

The association of the PICALM GG genotype with neurophysiological signs of hyperexcitability or disinhibition implies that carrier of this genotype may be prone to stress reactions. Previous studies have reported that long-standing distress in midlife increases the risk of AD (Johansson et al., 2014; Landfield et al., 2007; Lupien et al., 2007; Sousa et al., 2000).

Given that PICALM GG was reported to have genetics associated with the risk for $\mathrm{AD}$, the observed $G G$-associated neurophysiological alterations may have a potentially causative contribution to an increased risk for $\mathrm{AD}$, or alternatively, may be associated with the early physiological changes that occur decades before AD symptoms. Previous research has revealed the influence of the PICALM rs3851179 genotype on PICALM expression (Parikh et al., 2014). Because the PICALM protein modulates glutamatergic synaptic transmission (Harel et al., 2011) and glutamatergic mechanisms are essential for beta rhythm generation, it is possible that the EEG beta alterations found in the carriers of the PICALM GG genotype are mediated by the changes in glutamatergic neurotransmission.

The neurophysiological signs of hyperexcitability and/or cortical disinhibition in the PICALM GG carriers revealed in the present study may be related to the accumulation of pathogenic $A \beta$ assemblies many years before the manifestation of $\mathrm{AD}$ (Ando et al., 2013; Baig et al., 2010; Parikh et al., 2014), which may elicit aberrant excitatory network activity and epileptiform discharges that could lead to network disinhibition (LaFerla, 1995; Palop and Mucke, 2009). Tau accumulation in the carriers of the PICALM GG genotype may also contribute to neuronal hyperexcitability (DeVos et al., 2013; Moreau et al., 2014). These processes may be related to the early signs of degeneration in the hippocampus and entorhinal cortex in nondemented adults that have been associated with the PICALM SNP rs3851179 (Biffi et al., 2010). Further studies are needed to verify these hypotheses.

EEG alterations in the carriers of the PICALM GG genotype differ from those in the $A p o E \& 4$ allele carriers; however, both of these genetic risk variants underlie cerebral disinhibition and/or hyperexcitability. In a previous study, we found that the presence of the $A p o E \varepsilon 4$ allele in cognitively normal younger adults was associated with neurophysiological signs of hyperexcitability, which was characterized by the manifestation of synchronous high-voltage delta and theta activity and sharp waves under hyperventilation. It was suggested that aberrant network hyperactivity contributes to cognitive decline through changes in the expression of neuronal gene products and the remodeling of neuronal circuits (Palop and Mucke, 2010; Sanchez et al., 2012) (Bakker et al., 2015). Promising results have been obtained in recent studies demonstrating that the use of low doses of antiepileptic drugs can rescue neurophysiological alterations and cognitive deficits in mouse models of $A D$ (Sanchez et al., 2012), and in patients with amnestic MCI (Bakker et al., 2015).

In conclusion, this study found an increase in beta relative power associated with the AD risk PICALM GG genotype in nondemented adults, with the effect being more pronounced in subjects older than 50 years. This increase suggests cortical disinhibition and/or neuronal hyperexcitability in the carriers of the AD risk PICALM GG genotype, which is heightened during normal aging.

\section{Disclosure statement}

The authors have no actual or potential conflicts of interest. 


\section{Acknowledgements}

Research was supported by Russian Science Foundation grant no. 14-44-00077 (Aging-related genetic-EEG association study); coauthors were supported, in part, by Russian Science Foundation grant no. 14-15-01121 (genotyping of AD-gene), the grants from the Government of the Russian Federation (No 14.B25.31.0033), and NIH/NIA AG029360, N.V.P. was supported by RFBR grants No 11-0401896-a and No 15-04-08744-a.

\section{Appendix A. Supplementary data}

Supplementary data associated with this article can be found, in the online version, at http://dx.doi.org/10.1016/j.neurobiolaging. 2016.12.010.

\section{References}

Ando, K., Brion, J.P., Stygelbout, V., Suain, V., Authelet, M., Dedecker, R., Chanut, A., Lacor, P., Lavaur, J., Sazdovitch, V., Rogaeva, E., Potier, M.C., Duyckaerts, C., 2013. Clathrin adaptor CALM/PICALM is associated with neurofibrillary tangles and is cleaved in Alzheimer's brains. Acta Neuropathol. 125, 861-878.

Babiloni, C., Benussi, L., Binetti, G., Cassetta, E., Dal Forno, G., Del Percio, C., Ferreri, F., Ferri, R., Frisoni, G., Ghidoni, R., Miniussi, C., Rodriguez, G., Romani, G.L., Squitti, R., Ventriglia, M.C., Rossini, P.M., 2006a. Apolipoprotein E and alpha brain rhythms in mild cognitive impairment: a multicentric electroencephalogram study. Ann. Neurol. 59, 323-334.

Babiloni, C., Binetti, G., Cassarino, A., Dal Forno, G., Del Percio, C., Ferreri, F., Ferri, R. Frisoni, G., Galderisi, S., Hirata, K., Lanuzza, B., Miniussi, C., Mucci, A., Nobili, F., Rodriguez, G., Romani, G.L., Rossini, P.M., 2006b. Sources of cortical rhythms in adults during physiological aging: a multicentric EEG study. Hum. Brain Mapp. 27, $162-172$.

Babiloni, C., Del Percio, C., Lizio, R., Marzano, N., Infarinato, F., Soricelli, A., Salvatore, E., Ferri, R., Bonforte, C., Tedeschi, G., Montella, P., Baglieri, A., Rodriguez, G., Famà, F., Nobili, F., Vernieri, F., Ursini, F., Mundi, C., Frisoni, G.B., Rossini, P.M., 2014. Cortical sources of resting state electroencephalographic alpha rhythms deteriorate across time in subjects with amnesic mild cognitive impairment. Neurobiol. Aging 35, 130-142.

Baig, S., Joseph, S.A., Tayler, H., Abraham, R., Owen, M.J., Williams, J., Kehoe, P.G., Love, S., 2010. Distribution and expression of picalm in Alzheimer disease. J. Neuropathol. Exp. Neurol. 69, 1071-1077.

Bakker, A., Albert, M.S., Krauss, G., Speck, C.L., Gallagher, M., 2015. Response of the medial temporal lobe network in amnestic mild cognitive impairment to therapeutic intervention assessed by fMRI and memory task performance. Neuroimage Clin. 7, 688-698.

Benitez, B.A., Jin, S.C., Guerreiro, R., Graham, R., Lord, J., Harold, D., Sims, R., Lambert, J.C., Gibbs, J.R., Bras, J., Sassi, C., Harari, O., Bertelsen, S., Lupton, M.K., Powell, J., Bellenguez, C., Brown, K., Medway, C., Haddick, P.C.G., Van der Brug, M.P., Bhangale, T., Ortmann, W., Behrens, T., Mayeux, R., PericakVance, M.A., Farrer, L.A., Schellenberg, G.D., Haines, J.L., Turton, J., Braae, A., Barber, I., Fagan, A.M., Holtzman, D.M., Morris, J.C., Williams, J., Kauwe, J.S.K., Amouyel, P., Morgan, K., Singleton, A., Hardy, J., Goate, A.M., Cruchaga, C., 2014. Missense variant in TREML2 protects against Alzheimer's disease. Neurobiol. Aging 35, 1510.e19.

Bibbig, A., Traub, R.D., Whittington, M.A., 2002. Long-range synchronization of gamma and beta oscillations and the plasticity of excitatory and inhibitory synapses: a network model. J. Neurophysiol. 88, 1634-1654.

Biffi, A., Anderson, C.D., Desikan, R.S., Sabuncu, M., Cortellini, L., Schmansky, N., Salat, D., Rosand, J., 2010. Genetic variation and neuroimaging measures in Alzheimer disease. Arch. Neurol. 67, 677-685.

Buzsáki, G., 2006. Rhythms of the Brain. Oxford University Press, New York.

Cannon, J., Mccarthy, M.M., Lee, S., Lee, J., Börgers, C., Whittington, M.A., Kopell, N., 2014. Neurosystems: brain rhythms and cognitive processing. Eur. J. Neurosci. 39, 705-719.

Chauhan, G., Adams, H.H., Bis, J.C., Weinstein, G., Yu, L., Töglhofer, A.M., Smith, A.V., van der Lee, S.J., Gottesman, R.F. Thomson, R., Wang, J., Yang, Q., Niessen, W.J., Lopez, O.L., Becker, J.T., Phan, T.G., Beare, R.J., Arfanakis, K., Fleischman, D., Vernooij, M.W., Mazoyer, B., Schmidt, H., Srikanth, V., Knopman, D.S., Jack Jr., C.R., Amouyel, P., Hofman, A., DeCarli, C., Tzourio, C., van Duijn, C.M., Bennett, D.A., Schmidt, R., Longstreth Jr., W.T., Mosley, T.H., Fornage, M., Launer, L.J., Seshadri, S., Ikram, M.A., Debette, S., 2015. Association of Alzheimer's disease GWAS loci with MRI markers of brain aging. Neurobiol. Aging 36, 1765.e7.

De Geus, E.J., 2010. From genotype to EEG endophenotype: a route for post-genomic understanding of complex psychiatric disease? Genome Med. 2, 63.

DeVos, S.L., Goncharoff, D.K., Chen, G., Kebodeaux, C.S., Yamada, K., Stewart, F.R., Schuler, D.R., Maloney, S.E., Wozniak, D.F., Rigo, F., Bennett, C.F., Cirrito, J.R., Holtzman, D.M., Miller, T.M., 2013. Antisense reduction of tau in adult mice protects against seizures. J. Neurosci. 33, $12887-12897$.
Donner, T.H., Siegel, M., Fries, P., Engel, A.K., 2009. Buildup of choice-predictive activity in human motor cortex during perceptual decision making. Curr. Biol. 19, 1581-1585.

Enoch, M.A., Shen, P.H., Ducci, F., Yuan, Q., Liu, J., White, K.V., Albaugh, B. Hodgkinson, C.A., Goldman, D., 2008. Common genetic origins for EEG, alcoholism and anxiety: the role of CRH-BP. PLoS One 3, e3620.

Farrer, L.A., Cupples, A., Haines, J.L., Hyman, B., Kukull, W.A., Mayeux, R., Myers, R.H. Pericak-Vance, M.A., Risch, N., van Duijn, C.M., 1997. Effects of age, sex, and ethnicity on the association between apolipoprotein $\mathrm{E}$ genotype and $\mathrm{Alz}$ heimer's disease. A meta-analysis. APOE and Alzheimer Disease Meta Analysis Consortium. JAMA 278, 1349-1356.

Fernandez-Mendoza, J., Li, Y., Vgontzas, A.N., Fang, J., Gaines, J., Calhoun, S.L., Liao, D., Bixler, E.O., 2016. Insomnia is associated with cortical hyperarousal as early as adolescence. Sleep 39, 1029-1036.

Ford, M.G., Pearse, B.M., Higgins, M.K., Vallis, Y., Owen, D.J., Gibson, A., Hopkins, C.R. Evans, P.R., McMahon, H.T., 2001. Simultaneous binding of PtdIns(4,5)P2 and clathrin by AP180 in the nucleation of clathrin lattices on membranes. Science 291, 1051-1055.

Furney, S.J., Simmons, A., Breen, G., Pedroso, I., Lunnon, K., Proitsi, P., Hodges, A. Powell, J., Wahlund, L.-O., Kloszewska, I., Mecocci, P., Soininen, H., Tsolaki, M., Vellas, B., Spenger, C., Lathrop, M., Shen, L., Kim, S., Saykin, A.J., Weiner, M.W., Lovestone, S., 2011. Genome-wide association with MRI atrophy measures as a quantitative trait locus for Alzheimer's disease. Mol. Psychiatry 16, $1130-1138$.

Goate, A., Chartier-Harlin, M.C., Mullan, M., Brown, J., Crawford, F., Fidani, L., Giuffra, L., Haynes, A., Irving, N., James, L., Mant, R., Newton, P., Rooke, K., Roques, P., Talbot, C., Pericak-Vance, M., Roses, A., Williamson, R., Rossor, M. Owen, M., Hardy, J., 1991. Segregation of a missense mutation in the amyloid $\beta$ protein precursor gene with familial Alzheimer's disease. Nature 349, 704-706.

Golenkina, S.A., Gol'tsov, A.I., Kuznetsova, I.L., Grigorenko, A.P., Andreeva, T.V. Reshetov, D.A., Kunizheva, S.S., Shagam, L.I., Morozova, I.I., GoldenkovaPavlova, I.V., Shimshilashvili, K., Viacheslavova, A.O., Faskhutdinova, G. Gareeva, A.É., Zainnullina, A.G., Khusnutdinova, É.K., Puzyrev, V.P., Stepanov, V.A., Kolotvin, A.V., Samokhodskaia, L.M., Selezneva, N.D., Gavrilova, S.I., Rogaev, E.I., 2010. Analysis of clusterin gene (CLU/APOJ) polymorphism in Alzheimer's disease patients and in normal cohorts from Russian populations. Mol. Biol. (Mosk) 44, 620-626.

Hamilton, M., 1960. A rating scale for depression. J. Neurol. Neurosurg. Psychiatry 23, 56-62.

Harel, A., Mattson, M.P., Yao, P.J., 2011. CALM, a clathrin assembly protein, influences cell surface GluR2 abundance. Neuromolecular Med. 13, 88-90.

Harold, D., Abraham, R., Hollingworth, P., Sims, R., Gerrish, A., Hamshere, M.L Pahwa, J.S., Moskvina, V., Dowzell, K., Williams, A., Jones, N., Thomas, C. Stretton, A., Morgan, A.R., Lovestone, S., Powell, J., Proitsi, P., Lupton, M.K., Brayne, C. Rubinsztein, D.C. Gill, M., Lawlor, B., Lynch, A., Morgan, K. Brown, K.S., Passmore, P.A., Craig, D., McGuinness, B., Todd, S., Holmes, C. Mann, D., Smith, A.D., Love, S., Kehoe, P.G., Hardy, J., Mead, S., Fox, N., Rossor, M., Collinge, J., Maier, W., Jessen, F., Schürmann, B., van den Bussche, H., Heuser, I., Kornhuber, J., Wiltfang, J., Dichgans, M., Frölich, L., Hampel, H., Hüll, M. Rujescu, D., Goate, A.M., Kauwe, J.S.K., Cruchaga, C., Nowotny, P., Morris, J.C. Mayo, K., Sleegers, K., Bettens, K., Engelborghs, S., De Deyn, P.P., Van Broeckhoven, C., Livingston, G., Bass, N.J., Gurling, H., McQuillin, A., Gwilliam, R. Deloukas, P., Al-Chalabi, A., Shaw, C.E., Tsolaki, M., Singleton, A.B., Guerreiro, R. Mühleisen, T.W., Nöthen, M.M., Moebus, S., Jöckel, K.-H., Klopp, N. Wichmann, H.-E., Carrasquillo, M.M., Pankratz, V.S., Younkin, S.G., Holmans, P.A., O'Donovan, M., Owen, M.J., Williams, J., 2009. Genome-wide association study identifies variants at CLU and PICALM associated with Alzheimer's disease. Nat. Genet. 41, 1088-1093.

Hughes, C.P., Berg, L., Danziger, W.L., 1982. A new clinical scale for the staging of dementia. Br. J. Psychiatry 140, 566-572.

Illarioshkin, S.N., Ivanova-Smolenskaia, I.A., Markova, E.D., Shadrina, M.I., Kliushnikov, S.A., Zagorovskaia, T.V, Miklina, N.I., Slominskiĭ, P.A., Limborskaia, S.A., 2004. Molecular genetic analysis of hereditary neurodegenerative diseases. Genetika 40, 816-826.

Jaworska, N., Berrigan, L., Ahmed, A.G., Gray, J., Bradford, J., Korovessis, A. Fedoroff, P., Knott, V., 2012. Resting electrocortical activity in adults with dysfunctional anger: a pilot study. Psychiatry Res. 203, 229-236.

Jelic, V., Julin, P., Shigeta, M., Nordberg, A., Lannfelt, L., Winblad, B., Wahlund, L.-O. 1997. Apolipoprotein E epsilon 4 allele decreases functional connectivity in Alzheimer's disease as measured by EEG coherence. J. Neurol. Neurosurg. Psychiatry 63, 59-65.

Jeong, J., 2004. EEG dynamics in patients with Alzheimer's disease. Clin. Neurophysiol. 115, 1490-1505.

Jobert, M., Wilson, F.J., Roth, T., Ruigt, G.S.F., Anderer, P., Drinkenburg, W.H., 2013 Guidelines for the recording and evaluation of pharmaco-sleep studies in Man: the international pharmaco-EEG society (IPEG). Neuropsychobiology 67, 127-167.

Johansson, L., Guo, X., Duberstein, P.R., Hällström, T., Waern, M., Östling, S., Skoog, I. 2014. Midlife personality and risk of Alzheimer disease and distress: a 38-year follow-up. Neurology 83, 1538-1544.

John, E.R., Ahn, H., Prichep, L., Trepetin, M., Brown, D., Kaye, H., 1980. Developmental equations for the electroencephalogram. Science 210, 1255-1258.

Klimesch, W., 1999. EEG alpha and theta oscillations reflect cognitive and memory performance: a review and analysis. Brain Res. Brain Res. Rev. 29, 169-195. 
LaFerla, F.M., 1995. The Alzheimer's beta-amyloid peptide induces neurodegeneration and apoptotic cell death in transgenic mice. Behav. Pharmacol. 6 (suppl), 55.

Lambert, J.-C., Heath, S., Even, G., Campion, D., Sleegers, K., Hiltunen, M., Combarros, O., Zelenika, D., Bullido, M.J., Tavernier, B., Letenneur, L., Bettens, K., Berr, C., Pasquier, F., Fiévet, N., Barberger-Gateau, P., Engelborghs, S., De Deyn, P., Mateo, I., Franck, A., Helisalmi, S., Porcellini, E., Hanon, O., de Pancorbo, M.M., Lendon, C., Dufouil, C., Jaillard, C., Leveillard, T., Alvarez, V., Bosco, P., Mancuso, M., Panza, F., Nacmias, B., Bossù, P., Piccardi, P., Annoni, G., Seripa, D., Galimberti, D., Hannequin, D., Licastro, F., Soininen, H., Ritchie, K., Blanché, H., Dartigues, J.-F., Tzourio, C., Gut, I., Van Broeckhoven, C., Alpérovitch, A., Lathrop, M., Amouyel, P., 2009. Genome-wide association study identifies variants at CLU and CR1 associated with Alzheimer's disease. Nat. Genet. 41, 1094-1099.

Landfield, P.W., Blalock, E.M., Chen, K.-C., Porter, N.M., 2007. A new glucocorticoid hypothesis of brain aging: implications for Alzheimer's disease. Curr. Alzheimer Res. 4, 205-212.

Lee, T.W., Yu, Y.W.Y., Hong, C.J., Tsai, S.J., Wu, H.C., Chen, T.J., 2012. The influence of apolipoprotein e epsilon 4 polymorphism on qEEG profiles in healthy young females: a resting EEG study. Brain Topogr 25, 431-442.

Lehtovirta, M., Partanen, J., Kononen, M., Hiltunen, J., Helisalmi, S., Hartikainen, P., Riekkinen Sr., P., Soininen, H., 2000. A longitudinal quantitative EEG study of Alzheimer's disease: relation to apolipoprotein E polymorphism. Dement Geriatr. Cogn. Disord. 11, 29-35.

Leirer, V.M., Wienbruch, C., Kolassa, S., Schlee, W., Elbert, T., Kolassa, I.T., 2011. Changes in cortical slow wave activity in healthy aging. Brain Imaging Behav. 5, $222-228$.

Leocani, L., Toro, C., Manganotti, P., Zhuang, P., Hallett, M., 1997. Event-related coherence and event-related desynchronization/synchronization in the $10 \mathrm{~Hz}$ and $20 \mathrm{~Hz}$ EEG during self-paced movements. Electroencephalogr. Clin. Neurophysiol. 104, 199-206.

Levy-Lahad, E., Wasco, W., Poorkaj, P., Romano, D.M., Oshima, J., Pettingell, W.H., Yu, C.E., Jondro, P.D., Schmidt, S.D., Wang, K., et al., 1995. Candidate gene for the chromosome 1 familial Alzheimer's disease locus. Science 269, 973-977.

Liu, G., Zhang, S., Cai, Z., Ma, G., Zhang, L., Jiang, Y., Feng, R., Liao, M., Chen, Z., Zhao, B., Li, K., 2013. PICALM gene rs3851179 polymorphism contributes to Alzheimer's disease in an Asian population. Neuromolecular Med. 15, 384-388.

Lupien, S.J., Maheu, F., Tu, M., Fiocco, A., Schramek, T.E., 2007. The effects of stress and stress hormones on human cognition: implications for the field of brain and cognition. Brain Cogn. 65, 209-237.

Masdeu, J.C., Kreisl, W.C., Berman, K.F., 2012. The neurobiology of Alzheimer disease defined by neuroimaging. Curr. Opin. Neurol. 25, 410-420.

Moreau, K., Fleming, A., Imarisio, S., Lopez Ramirez, A., Mercer, J.L., JimenezSanchez, M., Bento, C.F., Puri, C., Zavodszky, E., Siddiqi, F., Lavau, C.P., Betton, M., O' kane, C.J., Wechsler, D.S., Rubinsztein, D.C., 2014. PICALM modulates autophagy activity and tau accumulation. Nat. Commun. 5, 4998.

Moretti, D.V., Prestia, A., Fracassi, C., Binetti, G., Zanetti, O., Frisoni, G.B., 2012. Specific EEG changes associated with atrophy of hippocampus in subjects with mild cognitive impairment and Alzheimer's disease. Int.J.Alzheimers.Dis 2012, 253153.

Naj, A.C., Jun, G., Reitz, C., Kunkle, B.W., Perry, W., Park, Y.S., Beecham, G.W., Rajbhandary, R.A., Hamilton-Nelson, K.L., Wang, L.S., Kauwe, J.S., Huentelman, M.J., Myers, A.J., Bird, T.D., Boeve, B.F., Baldwin, C.T., Jarvik, G.P., Crane, P.K., Rogaeva, E., Barmada, M.M., Demirci, F.Y., Cruchaga, C., Kramer, P.L., Ertekin-Taner, N., Hardy, J., Graff-Radford, N.R., Green, R.C., Larson, E.B., St George-Hyslop, P.H., Buxbaum, J.D., Evans, D.A., Schneider, J.A., Lunetta, K.L., Kamboh, M.I., Saykin, A.J., Reiman, E.M., De Jager, P.L., Bennett, D.A., Morris, J.C., Montine, T.J., Goate, A.M., Blacker, D., Tsuang, D.W., Hakonarson, H., Kukull, W.A., Foroud, T.M., Martin, E.R., Haines, J.L., Mayeux, R.P., Farrer, L.A., Schellenberg, G.D., Pericak-Vance, M.A., Alzheimer Disease Genetics Consortium, Albert, M.S., Albin, R.L., Apostolova, L.G., Arnold, S.E., Barber, R., Barnes, L.L., Beach, T.G., Becker, J.T., Beekly, D., Bigio, E.H., Bowen, J.D., Boxer, A., Burke, J.R., Cairns, N.J., 2014. Age-at-onset in late onset alzheimer disease is modified by multiple genetic loci. JAMA Neurol. 71, 1394-1404.

Palop, J.J., Mucke, L., 2009. Epilepsy and cognitive impairments in Alzheimer disease. Arch. Neurol. 66, 435-440.

Palop, J.J., Mucke, L., 2010. Synaptic depression and aberrant excitatory network activity in Alzheimer's disease: two faces of the same coin? Neuromolecular Med. 12, 48-55.

Parikh, I., Fardo, D.W., Estus, S., 2014. Genetics of PICALM expression and Alzheimer's disease. PLoS One 9, e91242.

Ponomareva, N., Andreeva, T., Protasova, M., Shagam, L., Malina, D., Goltsov, A., Fokin, V., Mitrofanov, A., Rogaev, E., 2013. Age-dependent effect of Alzheimer's risk variant of CLU on EEG alpha rhythm in non-demented adults. Front. Aging Neurosci. 5, 86

Ponomareva, N., Klyushnikov, S., Abramycheva, N., Malina, D., Scheglova, N., Fokin, V., Ivanova-Smolenskaya, I., Illarioshkin, S., 2014. Alpha-theta border EEG abnormalities in preclinical Huntington's disease. J. Neurol. Sci. 344, 114-120.

Ponomareva, N.V., Goltsov, A.Y., Kunijeva, S.S., Scheglova, N.S., Malina, D.D., Mitrofanov, A.A., Boikova, T.I., Rogaev, E.I., 2012. Age- and genotype-related neurophysiologic reactivity to oxidative stress in healthy adults. Neurobiol. Aging 33, 839.e11.

Ponomareva, N.V., Korovaitseva, G.I., Rogaev, E.I., 2008. EEG alterations in nondemented individuals related to apolipoprotein E genotype and to risk of Alzheimer disease. Neurobiol. Aging 29, 819-827.
Porjesz, B., Almasy, L., Edenberg, H.J., Wang, K., Chorlian, D.B., Foroud, T., Goate, A. Rice, J.P., O'Connor, S.J., Rohrbaugh, J., Kuperman, S., Bauer, L.O., Crowe, R.R., Schuckit, M.A., Hesselbrock, V., Conneally, P.M., Tischfield, J.A., Li, T.K., Reich, T. Begleiter, H., 2002. Linkage disequilibrium between the beta frequency of the human EEG and a GABAA receptor gene locus. Proc. Natl. Acad. Sci. U. S. A. 99, 3729-3733.

Porjesz, B., Rangaswamy, M., 2007. Neurophysiological endophenotypes, CNS disinhibition, and risk for alcohol dependence and related disorders. ScientificWorldJournal 7, 131-141.

Prichep, L.S., John, E.R., Ferris, S.H., Rausch, L., Fang, Z., Cancro, R., Torossian, C. Reisberg, B., 2006. Prediction of longitudinal cognitive decline in normal elderly with subjective complaints using electrophysiological imaging. Neurobiol. Aging $27,471-481$.

Raj, T., Shulman, J.M., Keenan, B.T., Chibnik, L.B., Evans, D.A., Bennett, D.A. Stranger, B.E., De Jager, P.L., 2012. Alzheimer disease susceptibility loci: evidence for a protein network under natural selection. Am. J. Hum. Genet. 90, 720-726.

Rangaswamy, M., Porjesz, B., 2014. Understanding alcohol use disorders with neuroelectrophysiology. Handb Clin Neurol 125, 383-414.

Rangaswamy, M., Porjesz, B., Chorlian, D.B., Wang, K., Jones, K.A., Bauer, L.O, Rohrbaugh, J., O’Connor, S.J., Kuperman, S., Reich, T., Begleiter, H., 2002. Beta power in the EEG of alcoholics. Biol. Psychiatry 52, 831-842.

Riemann, D., Spiegelhalder, K., Feige, B., Voderholzer, U., Berger, M., Perlis, M. Nissen, C., 2010. The hyperarousal model of insomnia: a review of the concep and its evidence. Sleep Med. Rev. 14, 19-31.

Rogaev, E.I., 1999. Genetic factors and a polygenic model of Alzheimer's disease. Genetika 35, 1558-1571.

Rogaev, E.I., Sherrington, R., Rogaeva, E., Levesque, G., Ikeda, M., Liang, Y., Chi, H. Lin, C., Holman, K., Tsuda, T., 1995. Familial Alzheimer's disease in kindreds with missense mutations in a gene on chromosome 1 related to the Alzheimer's disease type 3 gene. Nature 376, 775-778.

Rossini, P.M., Rossi, S., Babiloni, C., Polich, J., 2007. Clinical neurophysiology of aging brain: from normal aging to neurodegeneration. Prog. Neurobiol. 83, 375-400.

Rossiter, H.E., Davis, E.M., Clark, E.V., Boudrias, M.H., Ward, N.S., 2014. Beta oscillations reflect changes in motor cortex inhibition in healthy ageing. Neuroimage 91, 360-365.

Saletu-Zyhlarz, G.M., Arnold, O., Anderer, P., Oberndorfer, S., Walter, H., Lesch, O.M. Böning, J., Saletu, B., 2004. Differences in brain function between relapsing and abstaining alcohol-dependent patients, evaluated by EEG mapping. Alcohol Alcohol 39, 233-240.

Sanchez, P.E., Zhu, L., Verret, L., Vossel, K.A., Orr, A.G., Cirrito, J.R., Devidze, N., Ho, K. Yu, G.-Q., Palop, J.J., Mucke, L., 2012. PNAS plus: levetiracetam suppresses neuronal network dysfunction and reverses synaptic and cognitive deficits in an Alzheimer's disease model. Proc. Natl. Acad. Sci. U. S. A. 109, E2895-E2903.

Saunders, A.M., Strittmatter, W.J., Schmechel, D., George-Hyslop, P.H., PericakVance, M.A., Joo, S.H., Rosi, B.L., Gusella, J.F., Crapper-MacLachlan, D.R. Alberts, M.J., 1993. Association of apolipoprotein E allele epsilon 4 with lateonset familial and sporadic Alzheimer's disease. Neurology 43, 1467-1472.

Schmechel, D.E., Saunders, A.M., Strittmatter, W.J., Crain, B.J., Hulette, C.M., Joo, S.H., Pericak-Vance, M.A., Goldgaber, D., Roses, A.D., 1993. Increased amyloid betapeptide deposition in cerebral cortex as a consequence of apolipoprotein E genotype in late-onset Alzheimer disease. Proc. Natl. Acad. Sci. U. S. A. 90, 9649-9653.

Sherrington, R., Rogaev, E.I., Liang, Y., Rogaeva, E.A., Levesque, G., Ikeda, M., Chi, H. Lin, C., Li, G., Holman, K., Tsuda, T., Mar, L., Foncin, J.F., Bruni, A.C., Montesi, M.P. Sorbi, S., Rainero, I., Pinessi, L., Nee, L., Chumakov, I., Pollen, D., Brookes, A., Sanseau, P., Polinsky, R.J., Wasco, W., Da Silva, H.A., Haines, J.L., PerkicakVance, M.A., Tanzi, R.E., Roses, A.D., Fraser, P.E., Rommens, J.M., St GeorgeHyslop, P.H., 1995. Cloning of a gene bearing missense mutations in early-onset familial Alzheimer's disease. Nature 375, 754-760.

Siegel, M., Donner, T.H., Engel, A.K., 2012. Spectral fingerprints of large-scale neuronal interactions. Nat. Rev. Neurosci. 13, 121-134.

Sousa, N., Lukoyanov, N.V., Madeira, M.D., Almeida, O.F.X., Paula-Barbosa, M.M., 2000. Reorganization of the morphology of hippocampal neurites and synapses after stress-induced damage correlates with behavioral improvement. Neuroscience 97, 253-266.

Spielberger, C.D., Gorsuch, R.L., Lushene, P.R., Vagg, P.R., Jacobs, A.G., 1983. Manual for the State-trait Anxiety Inventory (Form Y), Manual for the Statetrait Anxiety Inventory STAI. Consulting Psychologists Press, Palo Alto, CA.

Spitzer, B., Blankenburg, F., 2011. Stimulus-dependent EEG activity reflects internal updating of tactile working memory in humans. Proc. Natl. Acad. Sci. U. S. A. 108 8444-8449.

Stam, C., Van der Made, Y., Pijnenburg, Y.A.L., Scheltens, P., 2003. EEG synchronization in mild cognitive impairment and Alzheimer's disease. Acta Neurol. (Napoli) 108, 90-96.

Tallon-Baudry, C., Mandon, S., Freiwald, W.A., Kreiter, A.K., 2004. Oscillatory synchrony in the monkey temporal lobe correlates with performance in a visual short-term memory task. Cereb. Cortex 14, 713-720.

Tsuno, N., Shigeta, M., Hyoki, K., Kinoshita, T., Ushijima, S., Faber, P.L., Lehmann, D. 2002. Spatial organization of EEG activity from alertness to sleep stage 2 in old and younger subjects. J. Sleep Res. 11, 43-51.

Van Beijsterveldt, C.E., Molenaar, P.C., de Geus, E.J., Boomsma, D.I., 1996. Heritability of human brain functioning as assessed by electroencephalography. Am. J. Hum. Genet. 58, 562-573.

Van der Hiele, K., Bollen, E.L.E.M., Vein, A.A., Reijntjes, R.H.A.M. Westendorp, R.G.J., van Buchem, M.A., Middelkoop, H.A.M., van Dijk, J.G. 
2008. EEG markers of future cognitive performance in the elderly. J. Clin. Neurophysiol. 25, 83-89.

Van Straaten, E., Scheltens, P. Gouw, A.A., Stam, C.J. 2014. Eyes-closed task-free electroencephalography in clinical trials for Alzheimer's disease: an emerging method based upon brain dynamics. Alzheimers Res Ther 6, 86.

Versavel, M., Leonard, J.P., Herrmann, W.M., 1995. Standard operating procedure for the registration and computer-supported evaluation of pharmaco-EEG data. "EEG in phase I" of the Collegium Internationale Psychiatriae Scalarum (CIPS). Neuropsychobiology 32, 166-170.

Vlahou, E.L., Thurm, F., Kolassa, I.-T., Schlee, W., 2014. Resting-state slow wave power, healthy aging and cognitive performance. Sci. Rep. 4, 5101.

Volf, N.V., Gluhih, A.A., 2011. Background cerebral electrical activity in healthy mental aging. Hum. Physiol. 37, 559.

Von Stein, A., Rappelsberger, P., Sarnthein, J., Petsche, H., 1999. Synchronization between temporal and parietal cortex during multimodal object processing in man. Cereb. Cortex 9, 137-150.
Vysata, O., Kukal, J., Prochazka, A., Pazdera, L., Valis, M., 2012. Age-related changes in the energy and spectral composition of EEG. Neurophysiology 44, 63-67.

Xiao, Q., Gil, S.C., Yan, P., Wang, Y., Han, S., Gonzales, E., Perez, R., Cirrito, J.R., Lee, J.M., 2012. Role of phosphatidylinositol clathrin assembly lymphoidmyeloid leukemia (PICALM) in intracellular amyloid precursor protein (APP) processing and amyloid plaque pathogenesis. J. Biol. Chem. 287 21279-21289.

Xu, W., Tan, L., Yu, J.-T., 2015. The role of PICALM in Alzheimer's disease. Mol Neurobiol. 52, 399-413.

Xu, W., Wang, H.F., Tan, L., Tan, M.S, Tan, C.C., Zhu, X.C, Miao, D, Yu, WJ, Jiang, T, Tan, L., Yu, J.T. Alzheimer's Disease Neuroimaging Initiative Group, 2016. The impact of PICALM genetic variations on reserve capacity of posterior cingulate in AD continuum. Sci. Rep. 6, 24480.

Yamawaki, N., Stanford, I.M., Hall, S.D., Woodhall, G.L., 2008. Pharmacologically induced and stimulus evoked rhythmic neuronal oscillatory activity in the primary motor cortex in vitro. Neuroscience 151, 386-395. 